\title{
TRIBUTE TO DR JAMES WILLIAMS
}

\author{
Lord Cooke of Thorndon*
}

A memorial service was held at Victoria University to honour the life and work of Dr James Williams, former Professor of English and New Zealand Law, Principal and then first ViceChancellor of the Victoria University of Wellington, who died suddenly at his home in Sydney on Monday, 12 January 1976.

Mr Justice Cooke spoke of Dr Williams and his contribution to the law.

The legal and academic career James Williams began in 1925 when on leaving the Auckland Grammar School he entered at Auckland University College. He had a year as a full-time student and then four years part-time. He graduated Bachelor of Laws, winning a Senior Scholarship, and then Master of Laws, with first-class honours. Although very successful in the examinations, he had reservations about the kind of formal legal education then offering, and in later years was determined to do better for his own undergraduates. On the other hand his practical training in the law he did value greatly. He was employed by the firm of Stanton, Johnstone and Spence, becoming an assistant to A H Johnstone, later Sir Alexander Johnstone, King's Counsel, a learned lawyer and powerful advocate, undoubtedly one of the most accomplished all-round barristers New Zealand has produced. Johnstone was a life-long inspiration to Williams, but it was the examination success that shaped the course of James' life. He was awarded the University of New Zealand Travelling Scholarship in Law and went up to Clare College, Cambridge, to undertake research for the degree of Doctor of Philosophy.

The subject of his dissertation was section 4 of the Statute of Frauds, an Act passed in the reign of Charles II and aimed largely at preventing the hoodwinking of juries in an age when parties to lawsuits were not allowed to give evidence themselves. The statute provided that actions could not be brought on certain alleged contracts unless they were evidenced by writing signed by the party to be charged. For one whose future was to be in

Lord of Appeal, Distinguished Visiting Fellow, Faculty of Law, Victoria University of Wellington. At the time of his memorial service, Lord Cooke was a judge of the Supreme Court of New Zealand, he would be appointed to the Court of Appeal soon after. The address was first published at [1974] NZLJ 75. 
academic law it was an almost perfect subject. It was self-contained: the law consisted of 11 lines of Caroline draftmanship and some 450 judicial decisions expounding it - so that every line was said to have cost a kings's ransom. And it gave opportunities to trace historical development and to lay bare the various oddities of strained reasoning whereby the Judges had striven to prevent the statute from itself being used as an instrument of fraud. Williams composed (a word of which he was fond and which describes aptly his own style of writing) what is likely always to remain the definitive work on the subject. Published by the Cambridge University Press, it was reviewed and reported on favourably by men in the front rank of English academic life: Holdsworth, Winfield, Hamson. It was the foundation of his international reputation as a scholar. After appointment to his chair at Wellington, he delighted in the joke of a philistine friend that he was indeed the Professor of Frauds. Cambridge made a deep impact on him. It was fitting that years later, when he was ViceChancellor of this University, Cambridge was able to add to his degrees an honorary Doctorate of Laws.

In 1932, on returning to Auckland he began to practise as a barrister only, but the early 1930s were not the economic years for venturers of that kind. A chair at Victoria University College became vacant on the appointment of Professor Cornish as SolicitorGeneral. Williams applied, buttressing his application by letters from a galaxy of the Auckland profession of those days - Johnstone, H P Richmond, G P Finlay, Northcroft, Meredith. His old teacher, Professor Algie, wrote of him as "a man of very mature judgment and exceptional scholarship". His Cambridge supervisor, Professor Hazeltine, an American then occupying the Downing chair, sent a cable, the Chairman of the College Council was Mr Phineas Levi, a barrister and solicitor of this city. The combination of professional and academic support was overwhelming. Williams became Professor of English and New Zealand Law at the age of 27.

If the Statute of Frauds was a restricted subject, the same could not be said of the range he was required to teach - partly because of the staff limitations of those years, partly at first because of the illness of the other Professor of those days, Professor Adamson. From the beginning Williams had to lecture on most of the subjects in the law syllabus. On some he was himself a beginner. His friend Professor I D Campbell has reminded me of a story he would tell against himself. His very first lecture at Victoria was in criminal law. As usual it began at 8 am He had prepared some notes, but by 8.35 they had been covered. His resources in that field being exhausted, he could only, with characteristic honesty, tell the class so: and the lecture thus ended fifteen minutes early.

Not withstanding these heavy teaching commitments and a formative role on the Council of Legal Education, he found time during his first phase at Victoria to prepare the second edition of the work since known as Salmond and Williams on Contracts. Sir John Salmond had left an incomplete text. The first editor, Winfield, left it untouched, adding his own 
contributions in square brackets, and expressing in his preface gentle regret with respect to the author's propositions that it could be difficult for an editor to find the best authority for some of them, or indeed any authority. Salmond, however, was entitled to a certain magisterial tone. Williams transformed the book; he estimated that about two-thirds of the second edition was his and always understandably regarded this as his best written work. Seldom can original author and editor have been more happily attuned: the substance is analytical - at its best profoundly so; the style lucid and even. Generally it is impossible from internal evidence to tell where Salmond ends and Williams begins. "We may say, then, that every agreement is an accepted offer": the idea is to be found in much that Salmond wrote: commitment to the simple, uncompromising proposition is the responsibility of Williams. It is not a book for the beginner or the casual reader: and on its publication in 1945 it had the misfortune to be unfairly reviewed in England in the Law Quarterly Review by one who has become the greatest inconoclastic lawyer of the age. But today, and almost certainly for many years to come, when any question of fundamental theory in contract law has to be tackled, no piece of writing, judgment or argument is complete without looking for and thinking about the treatment in Salmond and Williams.

His services to Victoria were interrupted by four years as Dean of the Faculty of Law at Sydney; but fortunately for this University he returned to occupy his old chair for a further five years from 1946. In that period Victoria possessed, in Williams, McGechan, Campbell and Braybrooke, a law teaching staff, substantially full-time, whose strength may have been unsurpassed anywhere in the English-speaking world. As a lecturer to larger classes he concentrated on basic principles, intermingled with precepts of professional ethics learnt from A H Johnstone. But probably he was at his best in the smaller, tutorial-type classes for the Master's degree. In a rather narrow room at the front of the Hunter Building, congested with books, papers and students, he would converse. He loved good conversation and companionship: all his life he gave of these generously. Whether in the tutorial or across the dinner table, different through the stimuli might be, the method was much the same: beginning at a point somewhat distantly removed from that destined to be reached; unhurried; at times apparently hesitant; inviting concentration. But one soon learnt that concentration was rewarding. The train of thought was almost always composed, the conclusion something for turning over in the mind afterwards. Above all he had the teacher's one priceless and indispensable gift. In a way not wholly definable, but mainly because of the sheer quality of his thought, he made the pupil interested. Almost imperceptibly the conventional hour of instruction could lengthen into two. Enduring bonds were forged. He created interest without devices of provocation. There was a classical restraint and balance in all his teaching and writing. "Conservative" would not be the right word: his book on that section of the Statute of Frauds ended with a recommendation for its repeal, the practical destruction of all the curious learning upon which he was the world's leading authority. Modern legislators have acted on the recommendation in part only, so his book is still 
consulted for practical purposes. It was he who gave the name "the authenticated signature fiction" to a judicial invention that has recently been troubling the New Zealand Courts.

Coupled with the classical cast of mind there was always the warmth. Many of his pupils remained firm friends in later years. Both in New Zealand and in Sydney he was very well liked by the Bench and the Bar: particular mention might be made of his friendships with Mr Justice Ostler and Mr Justice M Macarthur in this country and with Mr Justice Holmes of the New South Wales Court of Appeal. And his lively interest in people extended far beyond legal spheres. An example is his association with this University's rugby club, which led to his becoming President of the Wellington Rugby Football Union - an office which gave him much pleasure. A former President of the Students' Associations, Mr D B Wilson, Stipendiary Magistrate, has asked that special mention be made of his sympathy and receptiveness in matters affecting students. He relished professional shop and legal biography and anecdote. Though his practice as a barrister was limited, the law reports include several leading cases in which he appeared. He was particularly proud as a technical exercise of the first of these: G J Coles \& Co Ltd $v$ G J Coles (NZ) Ltd in 1933, when, quite against the merits, he persuaded Mr Justice Herdman that an Australian company could not prevent pirating of its name in New Zealand, because it had not traded here.

In contemplating where Williams stands as a legal scholar it is remarkable that all his important writing had been completed well before he was forty years of age; though happily, towards the end of his life, he renewed his connection with law books by his successful chairmanship of Associated Book Publishers of Australasia. New Zealand has had many competent legal writers, but perhaps there stand out three with a claim to the accolade of greatness. Salmond, of course; Sir Alexander Turner, whose regeneration of the Spencer Bower book is analyogous to Salmond and Williams, and who has honoured both Williams and the University by his presence today; and Dr James Williams. Sir Francis Adams must also come in the reckoning for his encyclopaedic work on Criminal Law. The output of Williams as a legal writer was not large, but its quality is unmistakable. In middle age he elected to move on to fresh challenges. In the law he will remain with us always, as a true scholar and a dear friend. 